6. Kurt, E. (1931) Basics of linear counterpoint. Moscow[in Russian].

7. Martinsen, K. (1996). A. Individual piano technique based on sound-making will. Moscow: Music Publishers[in Russian].

8. Polozov, S. (2010). Musical thinking as a factor in the formation and development of musical culture: an informational basis. Bulletin of Tomsk State University, P. 70-75 [in Russian].

9. Piaskovsky, I. (1987). Logic of musical thinking. Igor Boleslavovich. Kiev: Musical Ukraine, [in Russian].

10. Tsagarelli, Yu. (2008). Psychology of musical and performing activities. Tutorial. St. Pterburg: Composer. St. Petersburg [in Russian].

Стаття надійщла до редакції 13.12.2017

УДК 78.03:78.071.1.+787.61

DOI 10.31723/2524-0447-2018-26-41-52

Олена Анатолї̈вна Хорошавіна

https://orcid.org/0000-0001-9792-0134

кандидат мистецтвознавства, в. о. доцента

кафедри народних інструментів

ОНМА імені А. В. Нежданової

elkhguitar@ukr.net

\title{
КРЕАТИВНІСТЬ ЯК ФАКТОР ТВОРЧОЇ ВОЛІ У КОМПОЗИТОРСЬКІЙ ТА ВИКОНАВСЬКІЙ ДІЯЛЬНОСТІ
}

Метою статті є виявлення провідних аспектів феномена креативності як головного чинника творчої волі у композиторській та виконавській діяльності. Методологія статті базується на єдності таких методичних підходів як психологічний, музично-історичний, соціокультурний, аксіологічний та інтерпретативно-текстологічний. Наукова новизна визначається, з одного боку, виявленням нових напрямів дослідження феномена креативності як ключового у багатьох дослідженнях психології мистецтва, з іншого боку - поглибленим вивченням принципів виконавської та композиторської діяльності як творчого акту. Висновки. Найбільш значними характеристиками музики як особливої форми буття мистецтва можна назвати креативність, комунікативність, цілісність та синкретизм. Креативність при музикознавчому ракурсі вивчення уявляється фактором, що сприяє художньому освоєнню світу, що набуває особливого значення в умовах становлення нової світоглядної парадигми «глобальної креативності». Множинність творчих ідей та варіантів їх розв'язання можна розглядати як ознаку зрілої музично-продуктивної здатності та саме реалізація креативних установок особистості

(C) Хорошавіна О. А., 2018 
композитора й забезпечує волю їх творчого втілення. Креативні якості не є винятковими властивостями композиторів, креативність у такому же ступені є характерною рисою виконавия у його творчій діяльності, бо креативність слід розуміти як властивість, що забезпечує розвиток творчої особистості та її здатність до створення нового художнього явища, творчого продукту.

Ключові слова: креатівність, креативне мислення, психологія мистецтва, виконавське мистецтво, композиторська діяльність.

Khoroshavina Elena Anatolievna, Ph.D. in History of Arts, Associate Professor of Department of Folk Instruments of Odessa National A. V. Nezhdanova Academy of Music

Creativity as a factor of art will in composing and performing activities

The purpose of this article is to identify the leading aspects of the phenomenon of creativity as the main factor of creative freedom in composing and performing activities. The methodology of this article is based on the unity of such methodological approaches as psychological, musical-historical, socio-cultural, axiological, and interpretive-textual. Scientific novelty is determined, on the one hand, by the identification of new directions for the study of the phenomenon of creativity as key in many studies of the psychology of art, and on the other hand, by an in-depth study of the principles of performing and composing as a creative act. Conclusion. The most significant characteristics of music as a special form of the existence of art can be called creativity, interpersonal skills, integrity and syncretism. Creativity at the musicological perspective of learning, which seems to be a factor contributing to the artistic mastery of the world, is of particular importance in the context of the emergence of a new worldview paradigm of "global creativity». The multiplicity of creative ideas and their solutions can be viewed as a sign of mature musical and productive ability, and it is the realization of the creative attitudes of the composer's personality that ensures the freedom of their creative embodiment. Creative qualities are not the exclusive properties of composers, creativity is also a characteristic feature of the performer in his creative work, since it should be understood as a property that ensures personal development and the ability to create a new artistic phenomenon, a creative product.

Keywords: creativity, creative thinking, psychology of art, performing art, composer activity.

Хорошавина Елена Анатольевна, кандидат искусствоведения, и. о. доцента кафедры народных инструментов ОНМА им. А. В. Неждановой

Креативность как фактор творческой воли в композиторской и исполнительской деятельности.

Цель статьи - выявление ведущих аспектов феномена креативности как главного фактора творческой свободы в композиторской и исполнительской деятельности. Методология статьи базируется на 
единстве таких методических подходов как психологический, музыкально-исторический, социокультурный, аксиологический и интерпретативно-текстологический. Научная новизна определяется, с одной стороны, выявлением новых направлений исследования феномена креативности как ключевого во многих исследованиях психологии искусства, с другой углубленным изучением принципов исполнительской и композиторской деятельности как творческого акта. Выводы. Наиболее значительными характеристиками музыки как особой формы бытия искусства можно назвать креативность, коммуникабельность, целостность и синкретизм. Креативность при музыковедческом ракурсе изучения представляется фактором, способствующим художественному освоению мира, приобретает особое значение в условиях становления новой мировоззренческой парадигмы «глобальной креативности». Множественность творческих идей и вариантов их решения можно рассматривать как признак зрелой музыкально-производительной способности и именно реализация креативных установок личности композитора и обеспечивает свободу их творческого воплощения. Креативные качества не являются исключительными свойствами композиторов, креативность в такой же степени является характерной чертой исполнителя в его творческой деятельности, так как ее следует понимать как свойство, обеспечивающее развитие личности и способность к созданию нового художественного явления, творческого продукта.

Ключевые слова: креативность, креативное мышление, психология искусства, исполнительское искусство, колпозиторская деятельность.

Актуальність статті. Креативність, що розуміється як комплексний феномен, представляється єдиною, цілісною і злагоджено функціонуючою системою, розвиток і модифікація якої залежить, по-перше, від соціальних чинників, по-друге, від специфічних об’єктивних складових, що йдуть від виду діяльності та загальної професійної спрямованості творчості, по-третє, від індивідуальних особистісних проявів креативності конкретної людини. Так, прояви креативності в рамках музичної творчості можуть бути абсолютно різними не тільки в різних спеціалізаціях (виконавці, композитори), але і в межах однієї досліджуваної групи. Навпаки, в кожному разі ми будемо стикатися 3 абсолютно унікальними характеристиками, так як це безпосередньо пов’язано з індивідуальними властивостями особистості.

Метою статті є виявлення провідних аспектів феномена креативності як головного чинника творчої волі у композиторській та виконавській діяльності. Методологія статті базується на єдності таких методичних підходів як психологічний, музично-історичний, соціокультурний, аксіологічний та інтерпретативно-текстологічний. 
Наукова новизна визначається, з одного боку, виявленням нових напрямів дослідження феномена креативності як ключового у багатьох дослідженнях психології творчості, з іншого боку - поглибленим вивченням принципів виконавської та композиторської діяльності як творчого акту.

Огляд літератури за даною проблематикою. У більшості сучасних робіт, що вивчають феномен творчої індивідуальності, особливе місце приділяється поняттю креативності, про яку Д. Кирнарська говорить, як про таємничу здатність душі й розуму народжувати нове, а не відтворювати старе $[4,16]$. Етимологію цього поняття традиційно прослідковують від латинського слова «сrео - творити, створювати», або від повністю співпадаючого з ним за змістом англійського слова «сreate». Явище креативності є одним із ключових у багатьох дослідженнях психології творчості, що й пояснює множинність їі трактувань та визначень, яких, як стверджує К. Торшина, понад шістдесят. Пояснюється це тим, що прагнення обгрунтувати дефініцію креативності натрапляє на звичні «концептуальні схеми» [5]. Вони мало застосовні для даної категорії, у зв’язку із чим розуміння креативності прямо пов'язане із загальною методологією дослідження, у рамках якого й відбувається спроба обгрунтування даної категорії.

Основний виклад матеріалу. Аналізуючи у своїй роботі існуючі визначення креативності, К. Торшина виділяє серед них шість типів категорій. До першого типу відносяться визначення, іменовані автором гештальтистськими, у яких креативність розуміється як процес руйнування й зміни існуючого гештальта для формування й побудови кращого; до другого типу К. Торшина відносить інноваційні поняття креативності, спрямовані на оцінювання відповідно до рівня новизни результату творчого процесу; третій тип містить у собі естетичні або експресивні поняття креативності, у яких головний упор робиться на вираження творчих ідей та самореалізація творця; четвертий тип, згідно з концепцією К. Торшиної, містить у собі психоаналітичні або динамічні визначення креативності, що грунтуються на концепції взаємин Я, Воно й Понад-Я; до п’ятого типу дослідниця відносить проблемні визначення креативності, тобто можливість обгрунтування категорії креативності бачиться через розгляд процесів розв'язання проблемних завдань; i, нарешті, до шостого типу були віднесені всі ті визначення, які не підпадали ні під один з вище позгаданих типів, включаючи досить невизначені й дискусійні [7]. 
Як відомо, концепція креативності набула широкого поширення після виходу робіт американських вчених Дж. Гілфорда, Е. Торренса, Є. Торндайка. Після того як Дж. Гілфорд обгрунтував принципову відмінність між двома типами розумових процесів - конвергентним й дивергентним, проблема креативності стала розглядатися з позиції когнітивної психології. Підкреслимо, що Дж. Гілфорд основою креативності й здатності до творчості вважав саме дивергентний тип мислення, що лягло в основу численних досліджень, що продовжують та розвивають цю ідею. У своїх роботах Дж. Гілфорд виділяє шістнадцять факторів гіпотетичних здатностей, що характеризують креативність, а саме - рухливість розуму, швидкість, нестандартність та оригінальність мислення, особливу чутливість свідомості до проблеми й т. ін. Узагальнюючи характеристики зазначених якостей, Дж. Гілфорд дає їм загальне найменування - дивергентне мислення, визначаючи його як важливу й відносно самостійну складову інтелекту [5, 18].

Таким чином, дивергентне мислення трактується в першу чергу як здатність людини продукувати рівноцінні альтернативні один одному розв'язання творчого завдання у відповідь на мінливі обставини й нові ситуативні умови. Це дозволяє говорити про креативність як про багатоаспектне й багаторівневе явище, що розкривається за допомогою дивергентного мислення, яке, у свою чергу, можна розглядати як інтегральну цілісну основу креативності.

Вивчення структури креативного мислення приводить більшість дослідників цієї проблеми до висновку, що в основі креативного мислення лежать асоціації. М. Ковальова вважає, що «креативне мислення утворюється в результаті нових комбінацій асоціацій між елементами», та «чим більш віддаленими є асоціації між елементами, тим більш креативним уважається мислення - за умови, що ці асоціації відповідають вимогам завдання й характеризуються корисністю» $[5,19]$.

Таким чином, Дж. Гілфорд охарактеризував основні параметри феномена креативності: по-перше, це оригінальне судження й здатність виявляти широке асоціативне поле проблеми, знаходячи при цьому несподівані розв'язання поставлених завдань; по-друге, це вміння не тільки виявляти основні властивості розглянутого об'єкта, але й пропонувати нові можливості його застосування - «семантична гнучкість»; по-третє, це здатність людини переосмислити споконвічну форму стимулу таким чином, щоб створити можливість використання його властивостей, переосмислених по-новому; у четвертих, 
це можливість генерувати нестандартні ідеї в спонтанній ситуації «спонтанна семантична гнучкість» $[3,162]$.

Погоджуючись у головному з теорією Дж. Гілфорда, Є. Ільїн всетаки дозволяє собі ряд уточнень - «правомірним слід визнати підхід до проблеми закордонних психологів, які в проблемі креативності виділяють чотири аспекти: креативний процес (як здатність), креативний продукт, креативну особистість та креативне середовище. Під останнім розуміють сферу, структуру, соціальний контекст, що формують вимоги до продукту творчості» [3, 158].

Відзначимо, що під креативністю Е. Торренс розуміє вираження сприйнятливості «до проблем, дефіциту знань, їх дисгармонії, незгідності й т. ін.; фіксації цих проблем; пошуку їх розв'язання, висування гіпотез; й нарешті, формулювання та повідомлення результату розв'язання» $[3,158]$. Для виявлення рівня креативності підходу на всіх етапах творчого акту Е. Торренс та його однодумець у цьому питанні Е. Торндайк пропонують групу тестів, покликаних виявити існуючі здатності та прихований творчий потенціал.

Д. Кирнарська, так само як й ряд інших дослідників, вважали дану принципову позицію американських учених досить уразливою, тому що запропонована ними концепція не могла повною мірою відповідати своїм же завданням. Більшість сучасних досліджень, у яких задіяні тести Торренса, застосовують їх для виявлення чотирьох важливих показників креативності, а саме швидкості, гнучкості, оригінальності й розробленості. Д. Кирнарська вказує, що у прагненні краще зрозуміти креативність Е. Торренс та Е. Торндайк створили тести, у яких головна увага приділялася виявленню кількості й оригінальності розумового продукту.

Причому їх спосіб виявлення креативності представлявся Д. Кирнарській досить сумнівним, тому що, на ії думку, визначати креативність особистості відповідно до іїі ідей про використання «цегл, голок, газет, м'ячів та інших безвинних предметів досить незвичним способом» було не зовсім коректним $[4,16]$. Вона досить дотепно зауважує, що якщо пропоновані предмети для випробуваного не здобували нового значення й він не знаходив їм нового застосування, - тоді висновок тесту для нього був би невтішним [4].

Не випадково саме музикознавець Д. Кирнарська засумнівалася в абсолютній об'єктивності пропонованих тестів, тому що саме в сфері музичної творчості визначення творчих здібностей та ступеня креативності винятково за допомогою тестових завдань навряд чи можна 
розцінювати як досить об'єктивну оцінку. Це рівною мірою стосується як виконавської, так й композиторської творчості, тому що кожний з названих видів професійної музичної діяльності вимагає набагато більш складного підходу для розкриття його сутності.

Подібна ситуація привела до того, що в останній третині XX сторіччя практична психологія й психодіагностика були неспроможні виявити творчі здібності та креативні можливості особистості, застосовуючи для цього систему тестів. Більше того, стало очевидно, що результати, одержані за допомогою тестових перевірок, найчастіше не виявляли особистісні характеристики й унікальні креативні властивості, а були обумовлені походженням людини, іiі вихованням, а часом й банальною підготовкою до тесту. Для прояснення цієї непростої ситуації ряд вчених зайнялися докладним розглядом методології та теоретичним обгрунтуванням застосовуваних дефініцій, сформованих в області психології та індивідуальних відмінностей у розумовій діяльності.

Так, М. Ковальова слідом за К. Мартиндейлом стверджує, що креативність слід скоріше розуміти як генеральну рису особистості, ніж представляти їі як когнітивну здатність. При вивченні ступеня творчої волі й рівня креативності особистості багато вчених будують свої дослідження таким чином, що в їхніх роботах креативність з'являється як якийсь набір особистісних факторів.

Є. Ільїн у своїй роботі «Психологія творчості, креативності, обдарованості» пропонує розглядати творчість «як процес конструктивних перетворень інформації й створення інноваційних результатів, суб'єктивно та об'єктивно значимих» $[3,160]$, де креативність визначається ним як суб'єктивна «детермінанта творчості, системне (багатомірне, багаторівневе) психічне утворення» [3, 160].

Іншими словами, креативність визначається через здатність до вираження інноваційних змін у всіх життєвих сферах людського пізнання, що включають процеси мислення, комунікації й професійної діяльності «на рівнях: особистість (потенціал) - процес - результат» [3]. При цьому автор відзначає, що оскільки будь-який творчий процес $є$ реалізацією двох різноспрямованих тенденцій, а саме творчої тенденції, з однієї сторони, й тенденції руйнування й реконструкції існуючих стереотипів - 3 іншої, феномен творчої креативної поведінки можна трактувати як «творче руйнування».

Нерідко можна зіштовхнутися практично з синонімізацією понять креативності та творчого потенціалу, що є не цілком коректним. 
Феномен креативності має свою потенційну й актуальну форму, а тому й більш широке понятійне поле значень порівняно з поняттям творчого потенціалу. У потенційній формі креативність не усвідомлюється особистістю, але присутня як неясний образ, сприймається як близький за духом, але віддалений у часі, та, що особливо важливо - завжди готовий перейти у свою активну фазу — актуальну форму (виявлену креативність).

Явище креативності уявляється єдиною, цілісною та злагоджено функціонуючою системою, розвиток й модифікація якої залежить, по-перше, від соціальних факторів, по-друге, від специфічних об'єктивних складових, відповідних виду діяльності та загальної професійної спрямованості творчості, й, по-третє, від індивідуальних особистісних проявів креативності конкретної людини. Так, прояви креативності у рамках музичної творчості можуть бути зовсім різноспрямованими не тільки відносно до професійних спрямувань (виконавці, композитори), але й у рамках однієї досліджуваної групи.

Інакше кажучи, креативність, яка проявляється композиторами, не може бути єдиною незмінною підставою з повністю ідентичними характеристиками у всіх досліджуваних випадках. Навпаки, у кожному випадку ми будемо зустрічатися з унікальними характеристиками, тому що це прямо пов'язане з неповторними властивостями особистості. Отже, якщо розглядати психологічну структуру креативності, можна дійти висновку, що вона складається з мотиваційних, афективних, естетичних, інтелектуальних, екзистенціальних креативних параметрів.

Протягом усього шляху вивчення проблеми креативності багато дослідників, слідом за «першопроходцями» Е. Торренсом та його однодумцями, розробляли й пропонували власні параметри й критерії оцінювання креативності. М. Холодна в якості критеріїв креативності пропонує наступний комплекс властивостей інтелектуальної діяльності: швидкість, яку дослідниця трактує як наявність певної кількості ідей, що виникають в одиницю часу; оригінальність, як здатність продукувати нестандартні ідеї й знаходити несподівані розв'язання, що суттєво відрізняються від загальноприйнятих, типових відповідей; сприйнятливість, що розуміється М. Холодною як особлива чуйність, сприйнятливість та уважність до нестандартних деталей, а також здатність гнучко й швидко перемикатися з однієї ідеї на іншу; метафоричність, що розуміється нею як здатність працювати у фантастичному, «неможливому» контексті, схильність використовувати 
символічні, асоціативні засоби для вираження своїх думок, а також вміння у простому бачити складне й, навпаки, у складному - просте $[3,164]$. У такому разі можливість швидкого переходу від одного виду явищ до далекого за змістом іншого можна визначати як гнучкість мислення.

Показники креативності або дивергентних здатностей, як відзначається в багатьох дослідженнях, не можуть повною мірою відобразити або визначити можливі творчі досягнення людини ані в її повсякденному житті, ані в професійній діяльності. Широке коло інтересів та унікальна внутрішня інтелектуальна активність забезпечують особливу мотивацію креативної особистості, тому що креативність характеризує найвищий рівень активності, при якому особистість здатна переосмислювати й модифікувати соціальне оточення відповідно до іiї внутрішніх потреб, рушійних сил та особливої мотивації.

Здатність креативності до переосмислювання й перетворення попередніх точок зору й сталих уявлень можна вважати одними з найважливіших параметрів та динамічних характеристик креативності. У багатьох роботах, наприклад, у працях Л. С. Виготського, ця здатність прямо пов'язується з уявою та властивими для неї принципами емоційного мислення. Автор пише, що «мистецтво є робота думки, але зовсім особливого емоційного мислення, та, навіть після проведеного коректування, ми ще не розв'язали головне завдання, що стоїть перед нами. Потрібно не тільки з'ясувати найточніше, чим відрізняються закони емоційного мислення від інших типів цього процесу, потрібно ще далі показати, чим відрізняється психологія мистецтва від інших видів того ж емоційного мислення» $[2,70]$. Далі він вказує на те, що однією з найбільш важливих особливостей уяви є прагнення до «перекомбінування» образів.

Зазначимо, що, пояснюючи цей феномен, Л. Виготський у якості найбільш зручної підстави для визначення своєї позиції обирає сферу музики - пояснюючи процес формування творчого уявлення, він говорить про те, що вибір «уявлень, образів, дій, учинків, реплік підкоряється тим самим законам художніх зчеплень, яким підкоряються зчеплення звуків у мелодію» [2].

Процес формування творчих настанов та пов'язані з ним креативні спрямування свідчать про наявність у конкретної творчої особистості розвиненого внутрішнього плану дій, що є результатом прагнення структурувати свої власні інтереси, переконання, творчі прагнення й формулювати для самого себе творчі завдання, особис- 
тісну мотивацію. Іншими словами, без усвідомлено вибудуваного та ясно структурованого плану дій процес результативної творчості уявляється достатньо сумнівним.

Аналізуючи проблему творчої особистості, креативність можемо розглядатися як стан та як процес, що веде до розуміння феномена творчості. При цьому цілком природно можна співвідносити творчість та інтерпретацію, тому що будь-яка творчість припускає інтерпретацію, та будь-яка інтерпретація припускає якщо не творчість у повному обсязі (оскільки воля інтерпретації все-таки обмежується обсягом інформації, що втримується в об'єкті інтерпретації), то співтворчістю.

У нашому випадку особливу увагу слід приділити проявам особистісного вираження у творчості, реалізованого за допомогою креативних установок особистості - автоінтерпретації (О. Столетов), які багато у чому стикаються з категорією автокомунікації, чиє вивчення розпочатковане ще Ю. Лотманом у працях, присвячених семіотичним аспектам культури [6]. Під автокомунікацією він розуміє процес збільшення інформації в ході трансформації вихідного повідомлення в системі «Я - Я» за допомогою впливу зовнішнього коду, що зрушує контекстну ситуацію: «Функціонально текст використовується не як повідомлення, а як код, коли він не додає нам будь-яких нових відомостей до вже наявних, а трансформує самоосмислення особистості, що породжує тексти, та переводить уже наявні повідомлення в нову систему значень» [6, 167-168].

М. М. Бахтін в «Естетиці словесної творчості» позначив основний принцип естетичного освоєння будь-якого явища як погляд ззовні розглянутого об'єкта, підведення «трансцендентного тла»: «...Автор повинен знайти точку опори поза ним, щоб воно стало естетично завершеним явищем...» [1]. У цьому випадку необхідне відчуження як у просторовому, так й у часовому та значеннєвому варіантах.

Висновки. Найбільш значними характеристиками музики як особливої форми буття мистецтва можна назвати креативність, комунікативність, цілісність та синкретизм. Креативність при музикознавчому ракурсі вивчення уявляється фактором, що сприяє художньому освоєнню світу, що набуває особливого значення в умовах становлення нової світоглядної парадигми «глобальної креативності» (В. Яковлєв) [8].

Обговорення феномена творчої особистості у музичній культурі $є$ постійним об'єктом дослідження багатьох музикознавців, з демонструванням при цьому різного розуміння функціональних, психоло- 
гічних, художніх властивостей композитора й виконавця. Так, розглядаючи феномен композиторства, Д. Кирнарська відзначає, що на початковому етапі навчання композиторові дозволено застосовувати «м'яке копіювання», тобто йому дозволено, спираючись на існуючий композиторський досвід, створювати «варіантні копії чужої музики» [4, 270]. Однак справжнього художника відрізняє неухильне прагнення знайти свій голос та «неповторну музичну особистість». Саме в цьому прагненні та русі у бік знаходження себе в музиці головним союзником та помічником творчої особистості стає ії ж власна креативність.

Множинність творчих ідей та варіантів їх розв'язання можна розглядати як ознаку зрілої музично-продуктивної здатності та саме реалізація креативних установок особистості композитора й забезпечує волю їх творчого втілення. Креативні якості не є винятковими властивостями композиторів, креативність у такому ж ступені є характерною рисою виконавця у його творчій діяльності, бо креативність слід розуміти як властивість, що забезпечує розвиток творчої особистості та ії здатність до створення нового художнього явища, творчого продукту.

\section{СПИСОК ЛІТЕРАТУРИ}

1. Бахтин М. Эстетика словесного творчества. М., 1979. 424 с.

2. Выготский Л. Психология искусства / предисл. А. Леонтьева; коммент. Л. Выготского, В. Иванова; общ. ред. В. Иванова. 3-е изд. М.: Искусство, 1986. $573 \mathrm{c}$.

3. Ильин Е. Психология творчества, креативности, одаренности. СПб.: Питер, 2009. 448 с.

4. Кирнарская Д. Психология специальных способностей. Музыкальные способности / предисл. Г. Рождественского. М.: Таланты-XXI век, 2004. 496 с.

5. Ковалева Г. Взаимосвязи когнитивных, личностных и нейродинамических характеристик креативности : дис. ... канд. психол. наук : [спец.] 19. 00. 01 - общая психология, психология личности, история психологии / Пермский государственный институт искусства и культуры. Пермь, 2002. $169 \mathrm{c}$.

6. Лотман Ю. Автокоммуникация: «Я» и «Другой» как адресаты (О двух моделях коммуникации в системе культуры). Лотман Ю. Семиосфера. СПб.: Искусство-СПБ, 2000. С. 163-177.

7. Торшина К. Современные исследования проблемы креативности в зарубежной психологии. Вопросы психологии. 1998. № 4. С. 123-133.

8. Яковлев В. Философские принципы креативности. Вестник Московского университета. Серия 7: Философия. 1999. № 3. С. 43-51. 


\section{REFERENCES}

1. Bakhtin, M. (1979). Aesthetics of verbal creativity. M. [in Russian]

2. Vygotsky, L. (1986) Psychology of art / preface. A. Leontiev; Comments L. Vygotsky, V. Ivanova; total ed. V. Ivanova. 3rd ed. M.: Art. [in Russian]

3. Ilyin, E. (2009) Psychology of creativity, creativity, giftedness. SPb.: Peter. [in Russian]

4. Kirnarskaya, D. (2004) Psychology of special abilities. Musical Abilities / Preface G. Rozhdestvensky. M : Talanta-XXI century. [in Russian]

5. Kovaleva, G. (2002) Interrelations of cognitive, personal and neurodynamic characteristics of creativity: diss. on competition uch. degree of candidate psychologist. Sciences: [spec.] 19. 00. 01 - general psychology, personality psychology, history of psychology / Perm State Institute of Art and Culture. Perm. [in Russian]

6. Lotman, Yu.(2000) Autocommunication: «I» and «Other» as addressees (On two communication models in the culture system). Lotman Y. Semiiosphere. St. Petersburg: «Art-SPB». P. 163-177. [in Russian]

7. Torshina, K. (1998) Modern Studies of the Problem of Creativity in Foreign Psychology. Questions of psychology. No. 4. P. 123-133. [in Russian]

8. Yakovlev, V. (1999) Philosophical principles of creativity. Bulletin of Moscow University. Series 7, Philosophy. № 3. P. 43-51. [in Russian]

Стаття надійшла до редакції 20.12.2017

УДК 781.5

DOI: $10.31723 / 2524-0447-2018-26-52-62$

Федорова Олександра Валентинівна

https://orcid.org/0000-0002-6488-869X

здобувач кафедри музики і музичної етнографії

Одеської національної музичної академії ім. А. В. Нежданової, музичний редактор радіостаниї «Гармонія Світу», м. Одеса fedorova_oleksandra@ukr.net.

\section{КАТЕГОРІЯ «КЛАСИЧНЕ» В МАСОВОМУ СУСПІЛЬНОМУ СПРИЙНЯТТІ: ІСТОРИЧНИЙ І СУЧАСНИЙ ПОГЛЯД}

Мета роботи полягає у визначенні категорії класичного як поняття в широкому сенсі слова в сучасній суспільній свідомості. Багатогранний зміст поняття «класичного» має на увазі можливість широкого використання як в області предметного і матеріального аналізу речей, так i для аналізу нематеріальних: духовних, естетичних, культурних та інших цінностей. Методи дослідження - історико-логічний, структурнофункціональний, які дозволили проаналізувати і розкрити основні сторони досліджуваної категорії. Наукова новизна роботи полягає в розширенні

(C) Федорова О. В., 2018 